\title{
Remote spinal cord injury in mucopolysaccharidosis type IVA after cervical decompression
}

\section{Figure 1 Preoperative spinal cord MRI}
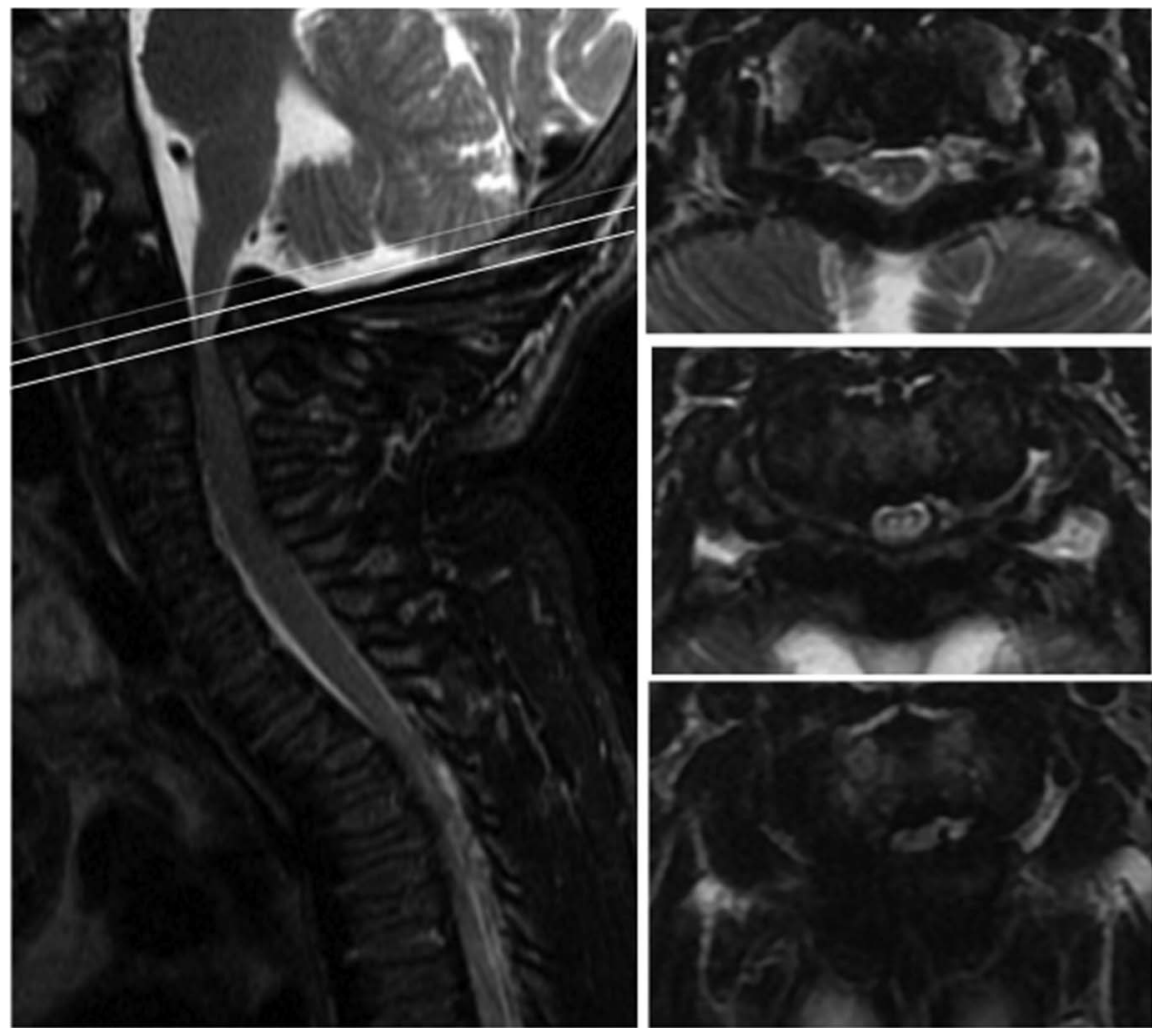

Sagittal T2-weighted image shows abnormal hyperintensity signal at C1 to C2 levels. The 2 upper axial images show the "snake eyes" myelomalacia appearance, secondary to ischemic lesion due to atlantoaxial subluxation; the lowest axial cut shows the maximum degree of spinal cord compression in this patient.

Morquio A syndrome (Online Mendelian Inheritance in Man \#253000) is a lysosomal storage disease caused by deficiency of N-acetylgalactosamine-6-sulfatase encoded by the GALNS gene. Key clinical features are skeletal dysplasia and short stature.

A 17-year-old boy with Morquio A syndrome had slowly progressive signs of spinal cord compression at C1 to C3. His examination showed Medical Research Council grade 3 in the upper and 2 in the lower limbs, hyperactive reflexes without clonus or Babinski sign, and no sensorial impairment. After occipitocervical fixation in the prone position, he developed acute paraplegia, sensory losses below T3, and striking MRI abnormalities (figures 1 and 2).

Patients with mucopolysaccharidosis may develop remote spinal cord injuries from compression sites after general anesthesia in the prone position due to impaired cardiac output. ${ }^{1}$ This outcome is unusual, ${ }^{1,2}$ but providers and patients should be alert to this possible complication.

Felippe Borlot, MD, Paula Ricci Arantes, MD, PhD, Alberto Carlos Capel Cardoso, MD, PhD,

Chong Ae Kim, $M D$, PhD

From the Instituto da Criança (F.B., C.A.K.), Hospital das Clínicas da Faculdade de Medicina da Universidade de São Paulo (HC FMUSP) (F.B., C.A.K., P.R.A., A.C.C.C.), Brazil. 


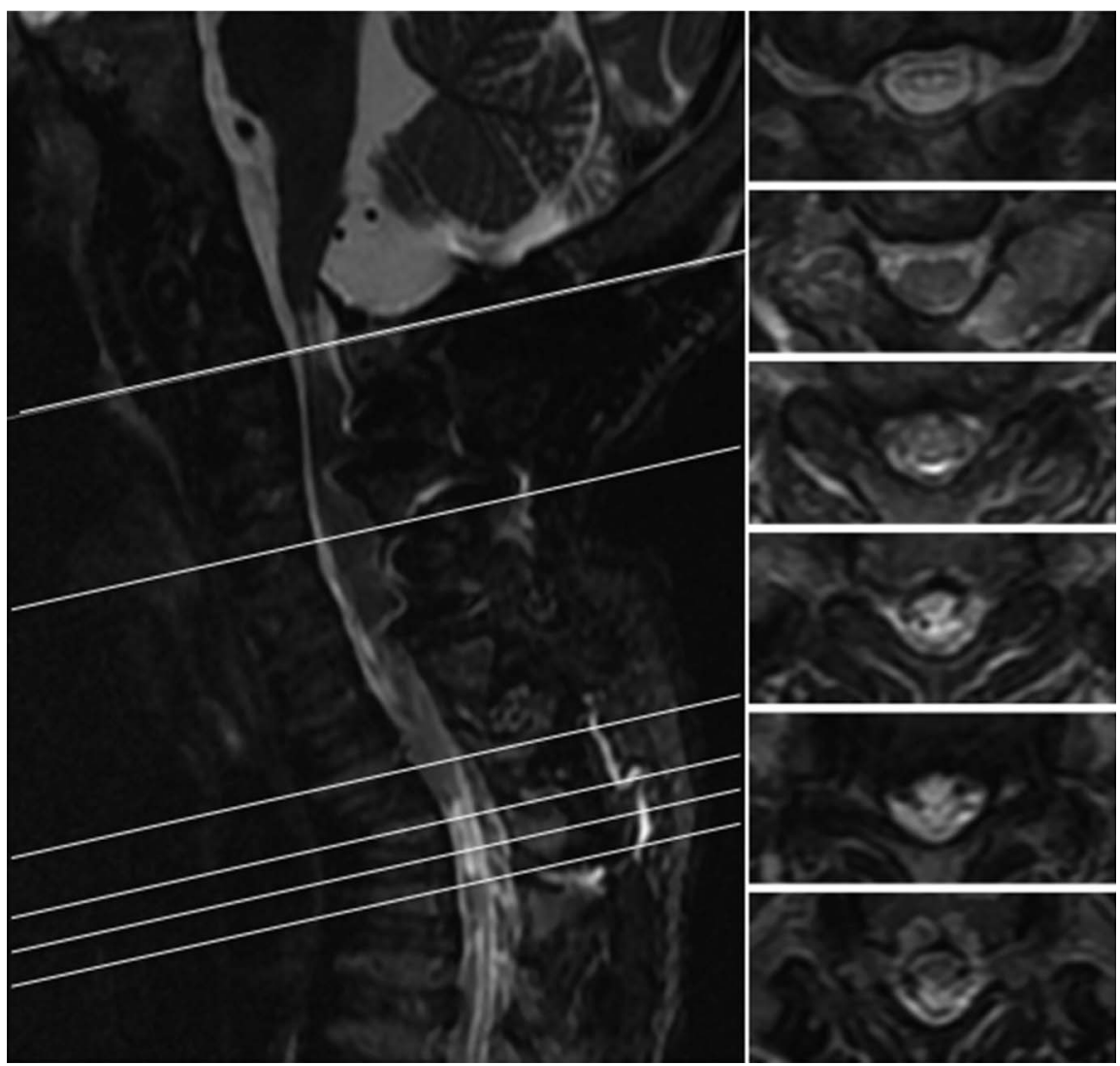

Sagittal and axial T2-weighted images. Persistent abnormal hyperintensity signal at C1 to C2 is seen in the sagittal and upper axial cuts; marked narrowing of cord with epidural lipomatosis and an extensive myelomalacia area from T2 to T6 is seen.

Author contributions: Dr. Borlot: study concept and design, drafting the manuscript, accepts responsibility for conduct of research, and acquisition of data. Dr. Arantes: drafting the manuscript, analysis or interpretation of data, accepts responsibility for conduct of research, and acquisition of data. Dr. Cardoso: analysis or interpretation of data, accepts responsibility for conduct of research, revising the manuscript, and final approval. Dr. Kim: interpretation of data, accepts responsibility for conduct of research, study supervision, and final approval.

Study funding: No targeted funding reported.

Disclosure: F. Borlot has received institutional research funding from the Neurology Division of the University of Toronto and received a travel grant for an expert testimony from BioMarin. P. Arantes, A. Cardoso, and C. Kim report no disclosures relevant to the manuscript. Go to Neurology.org for full disclosures.

Correspondence to Dr. Borlot: felippe.borlot@gmail.com

1. Tong CK, Chen JC, Cochrane DD. Spinal cord infarction remote from maximal compression in a patient with Morquio syndrome. J Neurosurg Pediatr 2012;9:608-612.

2. Möllmann C, Lampe CG, Müller-Forell W, et al. Development of a scoring system to evaluate the severity of craniocervical spinal cord compression in patients with mucopolysaccharidosis IVA (Morquio a syndrome). JIMD Rep 2013;11:65-72. 


\section{Neurology}

\section{Remote spinal cord injury in mucopolysaccharidosis type IVA after cervical decompression}

Felippe Borlot, Paula Ricci Arantes, Alberto Carlos Capel Cardoso, et al. Neurology 2014;82;1382-1383

DOI 10.1212/WNL.0000000000000341

\section{This information is current as of April 14, 2014}

\section{Updated Information \& Services}

References

Subspecialty Collections

Permissions \& Licensing

Reprints including high resolution figures, can be found at: http://n.neurology.org/content/82/15/1382.full

This article cites 2 articles, 0 of which you can access for free at: http://n.neurology.org/content/82/15/1382.full\#ref-list-1

This article, along with others on similar topics, appears in the following collection(s):

Metabolic disease (inherited)

http://n.neurology.org/cgi/collection/metabolic_disease_inherited MRI

http://n.neurology.org/cgi/collection/mri

Spinal cord infarction

http://n.neurology.org/cgi/collection/spinal_cord_infarction

Information about reproducing this article in parts (figures,tables) or in its entirety can be found online at:

http://www.neurology.org/about/about_the_journal\#permissions

Information about ordering reprints can be found online:

http://n.neurology.org/subscribers/advertise

Neurology ${ }^{\circledR}$ is the official journal of the American Academy of Neurology. Published continuously since 1951, it is now a weekly with 48 issues per year. Copyright () 2014 American Academy of Neurology. All rights reserved. Print ISSN: 0028-3878. Online ISSN: 1526-632X.

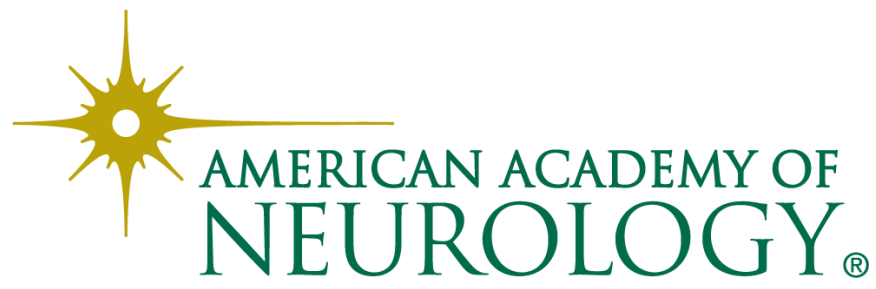

